A. TITLE: $\quad$ Pediatric positional sitting dermatitis: a new form of pediatric contact dermatitis

B. AUTHORS: $\quad$ Michael J Isaacs, BS $^{1}$ (First Author)

Matthew B Strausburg, MD ${ }^{1}$

Nico Mousdicas, MBCHB, MMED, $\mathrm{MD}^{1}$

${ }^{1}$ Indiana University School of Medicine, Department of

Dermatology

C. CORRESPONDING AUTHOR CONTACT INFORMATION:

Michael J Isaacs, BS

530 E. Ohio Street, \# 505, Indianapolis, IN 46202

mjisaacs@iupui.edu - Phone: 812-430-9787-Fax: 317 - 274-3700

D. KEYWORDS: $\quad$ Irritant contact dermatitis; posterior thigh dermatitis

E. RUNNING TITLE: Pediatric positional sitting dermatitis

F. WORD COUNT: $\quad 530$

G. AUTHOR CONSENT: Michael Isaacs, Matthew Strausburg, and Nico Mousdicas each give their written and verbal consent for this article to be submitted to Pediatric Dermatology.

H. CONFLICT OF

INTEREST: The authors have no conflict of interest to report.

I. INFORMED CONSENT: Informed consent for the following photographs and permission to publish these photographs was obtained from the parent or guardian of each patient.

This is the author's manuscript of the article published in final edited form as: Isaacs, M. J., Strausburg, M. B., \& Mousdicas, N. (2016). Pediatric Positional Sitting Dermatitis: A New Form of Pediatric Contact Dermatitis. Pediatric Dermatology, 33(3), e226-e227. https://doi.org/10.1111/pde.12858 


\begin{abstract}
:
We report 4 pediatric patients with a localized dermatitis in areas subject to repetitive friction due to their seating positions. We propose the cause of the eruption is an irritant contact dermatitis due to frequently sitting in a criss-crossed seated position, an entity for which we have coined the term "pediatric positional sitting dermatitis (PPSD)". Our goal with this report is to raise the clinician's awareness of PPSD, which to our knowledge has not been previously described, as well as to discuss management for these patients.
\end{abstract}

INTRODUCTION:

The differential diagnosis of a sharply localized dermatitis on the posterior thighs and lower buttocks in the pediatric population includes allergic or irritant contact dermatitis. Two examples of allergic contact dermatitis (ACD) are related to toilet seat exposure, often due to polypropylene within plastic toilet seats or allergens within the wood used to manufacture wooden toilet seats. ${ }^{1-2}$ Formaldehyde, dyes, and phenol found within varnishes and cleaning detergents applied to toilet seats represent additional allergens which commonly cause toilet seat dermatitis. ${ }^{1-2}$ Another notable cause of ACD includes school chair dermatitis secondary to nickel-containing fastenings or screws. ${ }^{3-4}$ Irritant contact dermatitis (ICD) should also be considered.

\title{
CASE SERIES:
}

Four pediatric patients presented with a recalcitrant moderately pruritic subacute dermatitis of the posterior thighs and lower buttocks (Table 1). Questioning revealed that each patient frequently sat in a criss-crossed seating position. Upon demonstration of these seating positions, 
each patient's shoes contacted their posterior thighs or buttocks in the exact areas of their dermatitis (Figure 1). Contact dermatitis was suspected and patch testing was negative with the North American series (65 allergens) in Patients 1 and 2; patch testing with a shoe allergen series (20 allergens) in Patient 2 was also negative, which included mercapto mix, aminobenzene, and various shoe dyes. In all 4 patients, treatment included avoidance of the criss-crossed seating position and daily topical corticosteroids which resulted in a resolution of symptoms within 2 to 6 weeks.

\section{DISCUSSION:}

These 4 cases of positional-induced localized dermatitis represent a previously unreported form of contact dermatitis, an entity that we propose calling "pediatric positional sitting dermatitis (PPSD)". We believe their dermatitis was caused by the repetitive contact between their shoes and skin, leading to the development of a localized ICD. Negative patch testing in 2 cases, historical exclusion of other causes, and examination of the patient's seating positions support a diagnosis of ICD. Each patient showed resolution following avoidance of the inducing seating position and short-term topical corticosteroids.

Distinguishing between ACD and ICD in cases of localized dermatitis is challenging. In many cases a negative patch test directs one to consider an ICD. Although patch testing was negative in Patients 1 and 2, we acknowledge that it does not completely rule out ACD as the culprit allergen may not have been tested. The true significance of PPSD, however, rests not upon ultimately diagnosing ICD or ACD, but rather upon recognizing this pattern first and foremost as a contact dermatitis. Furthermore, since ACD and ICD can be treated with trigger avoidance and 
topical steroids, we recommend that practitioners first implement empiric therapy before undergoing patch testing if PPSD is suspected. If no improvement is observed, patch testing may be appropriate.

In summary, we encourage practitioners to consider pediatric positional sitting dermatitis as a possible cause of pediatric posterior thigh and buttock dermatitis. By asking patients to demonstrate their seating positions, one can determine if these contact areas correspond with the presenting dermatitis. As school-aged children frequently sit in the criss-crossed position while wearing their shoes at home or at school, we believe PPSD may be more prevalent than is currently recognized and should be in the differential diagnosis of localized dermatitis in the pediatric population. Ultimately, future studies are needed to further characterize PPSD. 


\section{REFERENCES}

1. Heilig S, Adams DR, Zaenglein AL. Persistent allergic contact dermatitis to plastic toilet seats. Pediatr Dermatolog 2011;28:587-590.

2. Litvinov IV, Sugathan P, Cohen BA. Recognizing and treating toilet-seat contact dermatitis in children. Pediatrics 2010;125:e419-e422.

3. Hunt RD, Feldstein SI, Krakowski AC. Itching to learn: school chair allergic contact dermatitis on the posterior thighs. J Clin Aesthet Dermatol 2014;7:48-49.

4. Samimi SS, Siegfried E, Belsito DV. A diagnostic pearl: the school chair sign. Cutis $2004 ; 74: 27-28$

\section{FIGURE LEGENDS WITH CAPTIONS:}

Figure 1. A. Criss-crossed seated position demonstrated by Patient 4. B. Corresponding contact dermatitis of right posterior thigh.

Table 1. Characteristics of pediatric patients presenting with posterior thigh dermatitis 
Table 1.

\begin{tabular}{|c|c|c|c|c|c|c|c|c|}
\hline Patient & $\begin{array}{c}\text { Age } \\
\text { (Years) }\end{array}$ & Gender & $\begin{array}{l}\text { Duration } \\
\text { (Months) }\end{array}$ & Distribution & $\begin{array}{c}\text { Seating } \\
\text { Position(s) }\end{array}$ & Patch Test & $\begin{array}{l}\text { Initial } \\
\text { Treatment }\end{array}$ & Outcome \\
\hline 1 & 12 & $\mathrm{~F}$ & 12 & $\begin{array}{l}\text { Bilateral } \\
\text { posterior } \\
\text { thighs } \\
\text { Left buttock }\end{array}$ & $\begin{array}{l}\text { Criss-crossed } \\
\text { Asymmetric } \\
\text { tucking of } \\
\text { right foot } \\
\text { under left } \\
\text { buttock }\end{array}$ & $\begin{array}{l}\text { North } \\
\text { American } \\
\text { series }\end{array}$ & $\begin{array}{l}\text { Avoid } \\
\text { seating } \\
\text { position } \\
\text { Topical } \\
\text { steroid }\end{array}$ & $\begin{array}{l}\text { Resolution } \\
\text { in } 2 \text { weeks }\end{array}$ \\
\hline 2 & 7 & $\mathrm{~F}$ & 18 & $\begin{array}{l}\text { Bilateral } \\
\text { posterior } \\
\text { thighs }\end{array}$ & $\begin{array}{l}\text { Criss-crossed } \\
\text { Elevated on } \\
\text { bent knees } \\
\text { with feet } \\
\text { tucked under } \\
\text { contralateral } \\
\text { buttocks }\end{array}$ & $\begin{array}{l}\text { North } \\
\text { American } \\
\text { series } \\
\text { Shoe } \\
\text { grouping } \\
\text { series }\end{array}$ & $\begin{array}{l}\text { Avoid } \\
\text { seating } \\
\text { position } \\
\text { Topical } \\
\text { steroid }\end{array}$ & $\begin{array}{l}\text { Resolution } \\
\text { in } 6 \text { weeks }\end{array}$ \\
\hline 3 & 11 & $\mathrm{M}$ & 1 & $\begin{array}{l}\text { Bilateral } \\
\text { posterior } \\
\text { thighs }\end{array}$ & Criss-crossed & Deferred & $\begin{array}{l}\text { Avoid } \\
\text { seating } \\
\text { position } \\
\text { Topical } \\
\text { steroid }\end{array}$ & $\begin{array}{l}\text { Resolution } \\
\text { in } 4 \text { weeks }\end{array}$ \\
\hline 4 & 12 & $\mathrm{~F}$ & 3 & $\begin{array}{l}\text { Bilateral } \\
\text { posterior } \\
\text { thighs }\end{array}$ & Criss-crossed & Deferred & $\begin{array}{l}\text { Avoid } \\
\text { seating } \\
\text { position } \\
\text { Topical } \\
\text { steroid }\end{array}$ & $\begin{array}{l}\text { Resolution } \\
\text { in } 3 \text { weeks }\end{array}$ \\
\hline
\end{tabular}



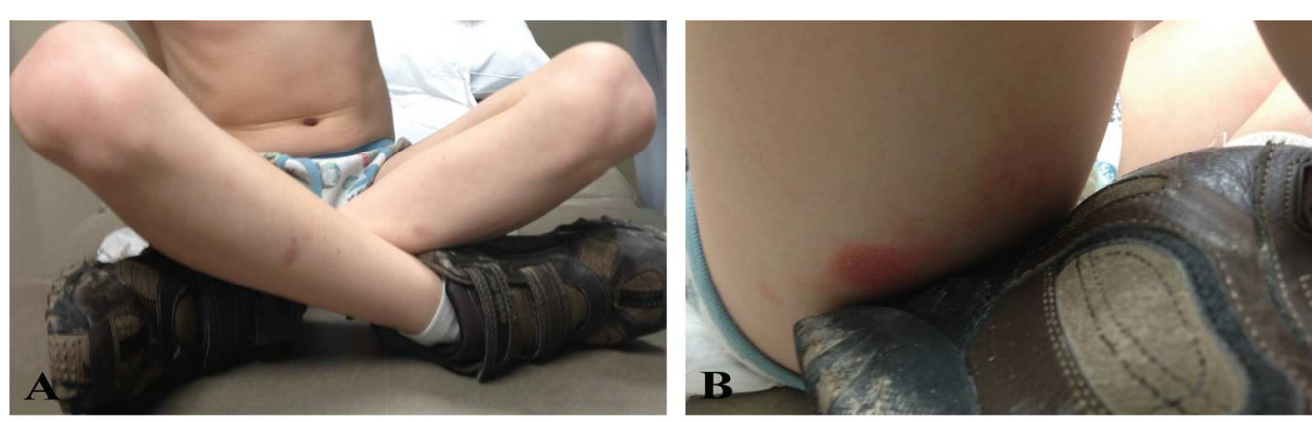

Figure 1A. Criss-crossed seated position demonstrated by Patient 3. Figure 1B. Corresponding contact dermatitis of right posterior thigh. $73 \times 22 \mathrm{~mm}(600 \times 600 \mathrm{DPI})$ 


\begin{tabular}{|c|c|c|c|c|c|c|c|c|}
\hline Patient & $\begin{array}{c}\text { Age } \\
\text { (Years) }\end{array}$ & Gender & $\begin{array}{c}\text { Duration } \\
\text { (Months) }\end{array}$ & Distribution & $\begin{array}{c}\text { Seating } \\
\text { Position(s) }\end{array}$ & Patch Test & $\begin{array}{c}\text { Initial } \\
\text { Treatment }\end{array}$ & Outcome \\
\hline 1 & 12 & F & 12 & $\begin{array}{c}\text { Bilateral } \\
\text { posterior } \\
\text { thighs } \\
\text { Left buttock }\end{array}$ & $\begin{array}{c}\text { Criss-crossed } \\
\text { Asymmetric } \\
\text { tucking of } \\
\text { right foot } \\
\text { under left } \\
\text { buttock }\end{array}$ & $\begin{array}{c}\text { North } \\
\text { American } \\
\text { series }\end{array}$ & $\begin{array}{c}\text { Avoid } \\
\text { sitting } \\
\text { position } \\
\text { Topical } \\
\text { steroid }\end{array}$ & $\begin{array}{c}\text { Resolution } \\
\text { in 2 weeks }\end{array}$ \\
\hline 2 & 7 & F & 18 & $\begin{array}{c}\text { Bilateral } \\
\text { posterior } \\
\text { thighs }\end{array}$ & $\begin{array}{c}\text { Criss-crossed } \\
\text { Elevated on } \\
\text { bent knees } \\
\text { with feet } \\
\text { tucked under } \\
\text { contralateral } \\
\text { buttocks }\end{array}$ & $\begin{array}{c}\text { North } \\
\text { American } \\
\text { series } \\
\text { grouping } \\
\text { series }\end{array}$ & $\begin{array}{c}\text { Avoid } \\
\text { sitting } \\
\text { position } \\
\text { Topical } \\
\text { steroid }\end{array}$ & Resolution \\
in 6 weeks \\
\hline 3 & 11 & M & 1 & $\begin{array}{c}\text { Bilateral } \\
\text { posterior } \\
\text { thighs }\end{array}$ & Criss-crossed & Deferred & $\begin{array}{c}\text { Avoid } \\
\text { sitting } \\
\text { position } \\
\text { Topical } \\
\text { steroid }\end{array}$ & Resolution \\
in 4 weeks
\end{tabular}

Table 1. Clinical characteristics of pediatric patients presenting with posterior thigh dermatitis. $35 \times 22 \mathrm{~mm}(300 \times 300 \mathrm{DPI})$ 